\title{
超過量有料制によるごみ処理有料化の 減量効果に及ぼす要因分析
}

\author{
和田 安彦1・三浦 浩之2・中野 加都子3 \\ 1フェロー会員 関西大学教授 工学部都市環境工学科 (广564-8680 大阪府吹田市山手町3-3-35) \\ E-mail:ywada@ipcku.kansai-u.ac.jp \\ 2 正会員 広島修道大学教授 人間環境学部人間環境学科 (7 731-3195 広島県広島市安佐南区大塚東1-1-1) \\ 3正会員 関西大学先端科学技術推進機構 (广564-8680 大阪府吹田市山手町3-3-35)
}

\begin{abstract}
日本ではごみ有料化方式の中で超過量有料制は少数派である.しかし，本方式は，具体的なごみ減量目 標を提示できることから，人々にはそれを達成するためのごみ減量意識が生まれる. 環境に配慮したいと 思っている市民にとっては，具体的な目標が設定されることが環境配慮行動を実践する場合の励みとなり， 実効性のある行動を選択させる。しかし, 無料で収集されるごみ量が多いと人々のごみ減量意識の向上を もたらさず，その量以上に減量努力しても経済的なメリットがないため，大部分の住民にごみ減量行動を 実行させることはできない．無料収集ごみ量とそれを超えたごみに対する徵収料金の設定が重要である.
\end{abstract}

Key Words : waste reduction, variable rate program, two-tier pricing

\section{1. 緒論}

2005年2月に中央環境審議会が「循環型社会の形成に 向けた市町村による一般廃棄物処理の在り方について」 意見具申し，これを受けて同年5月に「廃棄物の減量そ の他その適正な処理に関する施策の総合的かつ計画的な 推進を図るための基本的な方針」が告示された. そこで は，地方公共団体は経済的インセンティブを活用して一 般廃棄物の排出抑制や再生利用を推進し, 排出量に応じ た負担の公平化および住民の意識改革を進めるため，一 般廃棄物処理の有料化の推進を図るべきであることが示 されている.

循環型社会の形成を目指して，様々な物質が様々な段 階でリサイクルされることは増えてきているものの, 発 生する廃棄物そのものがさほど減量化していない現状を 踏まえて, 有料化という切り札を切ることを環境省が推 奨したともとらえられる.

実際，一般廃呆物処理の有料化制度を導入しようとす る自治体は増えており，この動きは大都市にも広がりつ つある. 例えば，京都市では，廃棄物問題を検討してき た有識者らの諮問組織である廃棄物減量等推進審議会が ごみ収集サービスの有料化を柱とする答申案「今後のご み減量施策のあり方」をまとめた 1 . そこでは，各家庭 が出す一般ごみには原則, 市が指定する有料の袋の使用 を義務付け，価格は容量30Lの袋で 1 枚20～40円に設定
すべきだと答申し，市議会で可決すれば2006年秋にも導 入する方針である.

同様に，家庭ごみの有料化を検討していた福岡市は， 2005年10月から処理手数料を $1 \mathrm{~L}$ 当たり 1 円とし，指定 ごみ袋の料金に上乗せする形で実施することを決めた²). 有料化は政令市では北九州市に次ぎ二例目となる．また， 札幌市でも有料化導入について検討を行っている33).

このように, 有料化制度が議論され, 導入されつつあ るのは，主に次のことが根拠となっている.

(i) ごみ減量の促進

(ii) 費用負担の公平化

また，これらに加えて，財政面への寄与もあるが，こ れについては，税の二重負担という問題も指摘されてお り，有料化制度により得た収入をどういう目的で用いる のかを明確に示すことが必要となっている.

今後, 有料化を導入していく人口規模の大きい都市で は，多様な市民からの同意を早急に得るために，中小市 町村で主流となっている単純従量方式ではなく, あえて 超過量方式を導入する動きも出てくると考えられる.こ の方式は，比較的市民に受け入れられやすい制度である 一方，ごみ減量効果の持続性が悪いと言われる.

そこで, 本研究では, 実際に超過量方式を導入した 自治体の住民を対象に，超過量方式に対する意識なら びにごみ減量意識・行動について調査した，そして，こ の方式がごみ減量に寄与できる方式であるのか, 市民に 
ごみ減量行動を促させるためには，どのような制度とす ればよいのかを検討した。

\section{2. 超過量方式}

\section{（1）家庭ごみ有料化制度}

山谷 ${ }^{5}$ は2005年2月に第2回全国都市家庭ごみ有料化ア ンケート調查を実施している. その結果によると, 全国 765市区のうち，有料化（定額有料方式および無料・指 定袋方式を除く）都市は全体の36.7\%に当たる270都市で あり, そのうちの $84.4 \%$ は単純従量方式となっており, 超過量方式を採用している都市は 35 市と $13.0 \%$ に過ぎな い. 山谷が行った2000年9月に実施した第1回調査)では, 有料化都市は136市（全体の $20 \%$ ）であったことから， この4年半で有料化制度を導入した都市が大幅に増えた ことがわかる．これは，先に示した環境省の今後の廃棄 物処理の方針に合致するものである.

また，この新たに有料化制度を導入した都市で採用さ れた方式の多くは単純従量方式であり, 本研究で対象と する超過量方式を採用した都市は，10市に過ぎない．こ れは，本方式では，(i)無料配布にかなりの事務コスト・ 手間がかかること, (ii)無料配布枚数・配布袋容量の設定 を適切に行わないと減量効果が現れないこと, (iii)世帯 人数別に無料配布枚数等を設定しないと有効な減量対策 とならないこと等によると考えられる. さらに，無料配 布枚数の範囲を超えないようにごみを減量化しようとイ ンセンティブは働くものの, それ以上の減量インセンテ イブが働かないことや，超過した場合に市民が負担寸る コストが単純従量方式と比較して低額のため, 市民の生 活様式の変化による排出ごみ量の増加などによるリバウ ンドを抑えきれないことも指摘されている゙5)。このため, 出雲市ではごみ減量効果を強化するため, 超過量方式 （年間無料配布枚数 100 枚，超過料金 40 円 $/ 30$ 袋）から 単純従量方式 $(40$ 円 $/ 30 \mathrm{~L}$ 袋) 一と手数料体系を変更し ている. さらに, 山谷による調査において, 今後, 手数 料体系の見直しを検討している都市は9市であったが， その寸べてが超過量方式から単純従量方式への変更を検 討しているということが報告されている.

超過量方式はごみ減量効果が長続きせず，リバウンド が生じる方式と認識されており, 現時点では, その導入 が大きく増えるとは考えにくい，しかし，本方式は，一 定量までは無料であることから，有料制として市民の賛 同を得やすい方式である.

山川ら 7,89 による有料化実施時におけるごみ減量の影響 要因に関する研究で, 超過量方式 (一定量無料制有料 化）においても減量効果があることが示されている。 こ の理由として，一定量まで減量すれば無料になるという
具体的な目標が生じることで咸量行動が励起されること， 一定枚数以上排出して有料になることを罰金のように認 知して減量行動を行うようになることが考えられていた. しかし, 無料配布枚数が100枚／年を超えると, 配布枚 数の増加に伴いごみ減量率が低下寸る傾向のあることも 指摘されている.

しかし，現時点では有料化制度導入都市の大半は人口 15 万人未満であり（先の山谷による調査では，人口 15 万 人以上で有料化制度を導入しているのは24市，人口 30 万 人以上では6市に過ぎない， 今後, 有料化を導入して いく人口規模の大きい都市では, 様々な価值観, ライフ スタイルを持つ市民の同意を得るために，単純従量方式 ではなく超過量方式を導入する動きも出てくると考えら れる。

\section{（2）超過量方式の実態}

次に, 各自治体で導入されている超過量方式の実態に ついて, 山谷による調査功整理した.

35市のうち，世帯人数により無料配布枚数を変えてい るのは24市 $(69 \%)$ であり，11市では無料配布枚数は世 帯人数を考慮していない.

ごみ減量へのインセンティブを働かせるためには，世 帯人数を考慮する方がより望ましいと考え，ここでは， 世帯人数により無料配布枚数を変えている都市での実態 を分析してみる.

まず，標準的な4人世帯における無料配布枚数がどの 程度であるかをみると（図一 1），配布枚数はおよそ60 〜150枚であり，平均配布枚数は107枚である. 週2回の 収集で，各収集日1枚を使用するという設定が基準であ ることがわかる. なお，袋1枚の容量は30４5Lである.

次に，無料配布枚数を超過した後の指定袋購入料金を みてみる（図一2）。ここでは，大袋（45L）1枚の価格 を用いた。

100円が9市，50円〜100円未満が8市（うち50円が5市） であり，1枚当たり100円もしくは50円，あるいはその中 間值と設定している都市が多い。これは, 単純従量方式 で40円／袋としている都市が52市と最も多く，次いで30 円／袋（44市），20円／袋（34市），50円（32市）の順 となっていて，100円／袋を超える都市が1市しかないこ とと比較すると, 超過量方式ではごみ減量を意識して, 超過した場合の指定袋購入料金を単純従量方式よりも高 く設定していることがわかる.

この超過分の指定袋購入料金が人口規模および無料配 布枚数とどのような関わりを持っているのかを検討する (図一 3，4）。

人口規模が大きいほど，無料配布枚数が多いほど超過 分用指定袋購入料金（以下，超過料金）が高めになる傾 向がみられる. どちらも相関としては高いものではない 
が，人口規模よりも無料配布枚数の方が超過料金設定に 影響しており，無料配布枚数が多い都市ほど超過料金は 高く設定される傾向がある. 例えば，無料配布枚数が50 枚程度であれば，超過料金は50円／袋程度，100枚程度 ならば100円／袋程度である。

\section{3. 超過量方式導入自治体でのごみ排出実態}

可燃ごみに対してシール制による超過量方式を導入し ている大阪府東南部に近接しているA市（人口126,000 人）, $\mathrm{B}$ 町（人口 17,000 人）におけるごみ排出実態を調 查した. A市とB町は, 他の5市町村と清掃施設組合を組 織している．その分別収集区分は，「もえるごみ」,

「もえないごみ・粗大ごみ」, 「資源ごみ」であり, 資 源ごみはペットボトル，プラスチック製容器包装，か ん・びんなどに細分される. 超過量方式の対象となるの は「もえるごみ」と「もえないごみ・粗大ごみ」であり， それぞれ指定シールの貼付が必要である.

A市は昭和20年代の市制施行以降, 地域の中心的な田 園都市として発展してきた. その後, 高度経済成長時代 の大阪都市圈の人口急増のもとで, 西部の丘陵地域を中 心に大小の住宅地開発が次々と行われ，最近では住宅都 市へと変貌しつつ, 現在に至っている.

$\mathrm{B}$ 町は古くから開けた地域で, 多くの古墳・遺跡が残 る, 自然と歴史に恵まれた緑豊かな町である.このため, 大阪府下にあっても総人口に対する農家人口の割合が $22.9 \%(2000)$ と比較的高い（農林水産省「2000年世界農林 業センサス（農業編）」による）。また，町民のボラン ティア活動も活発に行われている.

両市町で導入している「もえるごみ」に対する超過量 方式の概要を表一 1 に示寸. シールの配布枚数は世帯構 成により異なり，一定量のごみを排出した後に必要とな る有料シール価格はごみ袋容量により異なっている. な お，余った無料シールは次年度に繰り越しはできない。

ここで，全国で超過量方式を導入している市町におけ る両自治体の位置づけをみてみる.

A市は人口としては導入市町の中では比較的人口が多 い方であり, 無料配布枚数もやや多い部類である. 超過 料金は他の導入市町と同様である.

一方，B町は導入市町の中において，人口が最も少な い方であり, その人口規模からするとやや無料配布枚数 は多い部類となる．超過料金はA市と同じである.

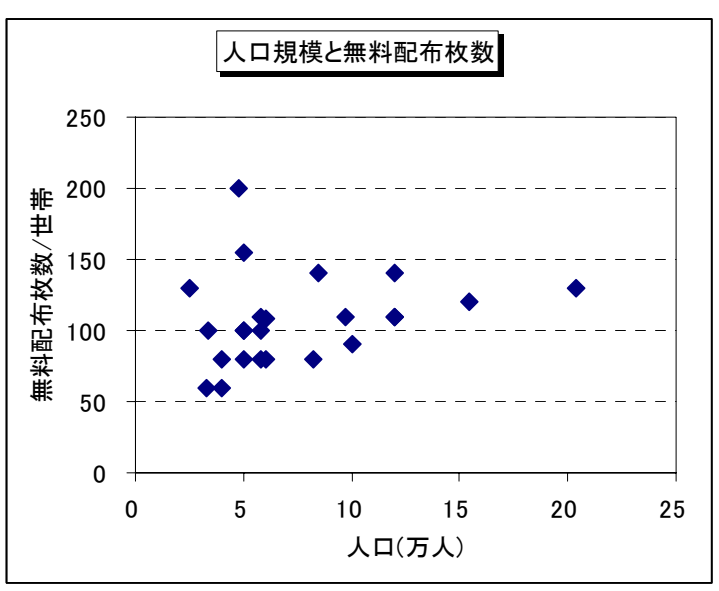

図-1 人口規模と無料配布枚数の関係

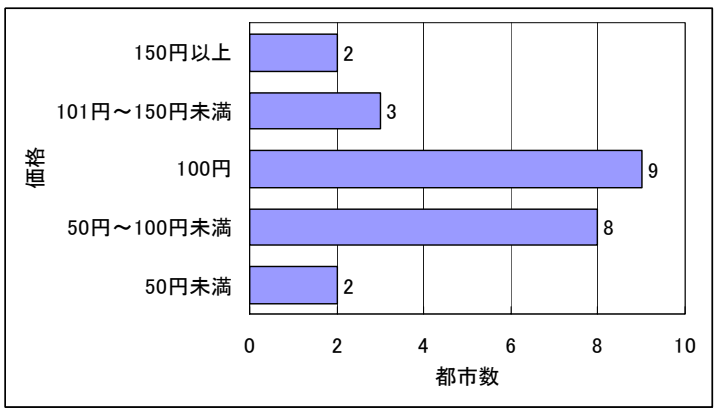

図-2 超過分用指定袋購入料金

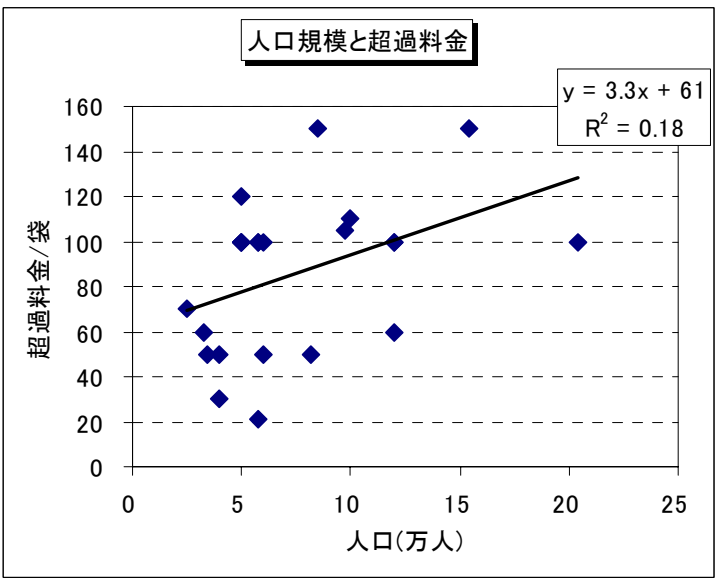

図－3人口規模と超過分用指定袋購入料金の関係

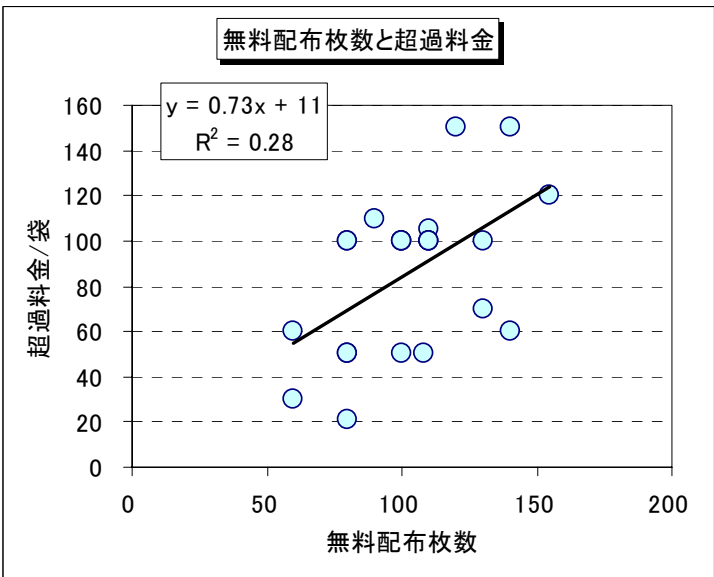

図-4 無料配布枚数と超過分用指定袋購入料金の関係 


\section{4. 超過量方式に対する市民の評価・意識}

\section{（1）アンケート調査の概要}

調查は，2003年9～10月にA市・B町在住の一般住民を 対象に直接用紙を配布し，簡単な説明のあと時間をおい て回収する訪問留め置き法により行った，また，標本抽 出は無作為抽出法により行った. 有効回答数はA市260, B町272である（調查時の世帯数 A市：47,360, B町： $6,090)$.

調査内容は，以下のものである.

\begin{tabular}{|l}
\hline I. 有料化の賛否 \\
(1) 有料化 (超過量方式) が実施される以前と現在の有料化に \\
対する意識の変化 \\
(2) 有料 (超過量方式) に賛成する理由（または反対する理 \\
由)
\end{tabular}
由)

II. もえるごみ処理シールの使用状況ともえるごみ減量行動

(1) 前年のもえるごみ処理シール使用状況

(2)【無料シールが余った人に対して】前年に無料シールが余 ったことを踏まえて実行しているごみ減量行動

(3)【さらに無料シールが余るようにごみ減量努力する人に対 して】さらにごみ減量努力する理由

(4)【有料シールを購入した人に対して】前年に有料シールを 購入したことを踏まえて害行しているごみ減量行動

III. 行っているもえるごみ減量行動

(1) 提示したごみ減量行動の実行状況

IV. 有料化直後と現在のもえるごみの減量意識と行動

(1) 有料化（超過量方式）が実施された直後から現在までの無 料シールおよび有料シールの使用状況

(2) 余った無料シール枚数，または, 購入した有料シール枚数 の現在までの変化動向

(3) 有料化実施直後と現在とにおけるごみ減量意識の変化

(4) 減量意識が向上した，あるいは低下した理由

V. 有料化制度と可燃ごみ減量行動の関係

(1) 提示した有料制度 (無料シール配布枚数, 有料シール価 格, ごみ袋容量）が導入されたときのごみ減量行動の実行 予測

フェイスシート

回答方式はいずれもプリコード回答である．表一2に 調查概要を示す，なお，対象となるごみは “可燃ごみ （もえるごみ）”である. 以下では特に断らない限り， アンケート調査にかかわる記述での “ごみ”は “可燃ご み”を指す。

なお，本論文では A 市住民と B 町住民の回答を一体 として解析している.これは同じ清掃施設組合で処理し ていることから導入している制度が同じであること，ご み処理有料制（超過量方式）に対する意識や行動は，居 住地よりも個人の価値観やライフスタイルに，より影響 されると考えたからである.
表-1 導入している超過量方式の内容

\begin{tabular}{|l|c|}
\hline 有料化導入時期 & 平成 8 年度 \\
\hline シール配布枚数 & 1 2人 30L用 110 枚 \\
\cline { 2 - 2 } & 3 4人 45L用 110 枚 \\
\cline { 2 - 2 } & 5 6人 $45 \mathrm{~L}$ 用 140 枚 \\
\cline { 2 - 2 } & 7人以上 $45 \mathrm{~L}$ 用 170 枚 \\
\hline 有料シール価格 & 45L用袋 100 円 $/$ 枚 \\
\cline { 2 - 2 } & 30L用袋 50 円 $/$ 枚 \\
\hline シール配布時期 & 年 2 回 \\
\hline 燃えるごみ収集回数 & 週 2 回 \\
\hline
\end{tabular}

\begin{tabular}{|c|c|c|}
\hline 調査地域 & A市 & B町 \\
\hline 標本数 & 260 & 272 \\
\hline 有効回答率 & $87.0 \%$ & $79.1 \%$ \\
\hline 調査日 & $\begin{array}{r}\text { 平成15年 } 9 \text { 月 } 6 \text { 日 } \\
9 \text { 月 } 20 \text { 日 } \\
10 \text { 月 } 4 \text { 日 }\end{array}$ & $\begin{array}{r}\text { 平成15年 } 9 \text { 月 } 13 \text { 日 } \\
9 \text { 月 } 22 \text { 日 } \\
\text { 9月 } 27 \text { 日 } \\
10 \text { 月 } 11 \text { 日 } \\
10 \text { 月 } 25 \text { 日 }\end{array}$ \\
\hline 調査方法 & 訪問留め置き法 & 訪問留め置き法 \\
\hline 調査人員 & $3 \sim 4$ 人 & 1〜4人 \\
\hline
\end{tabular}

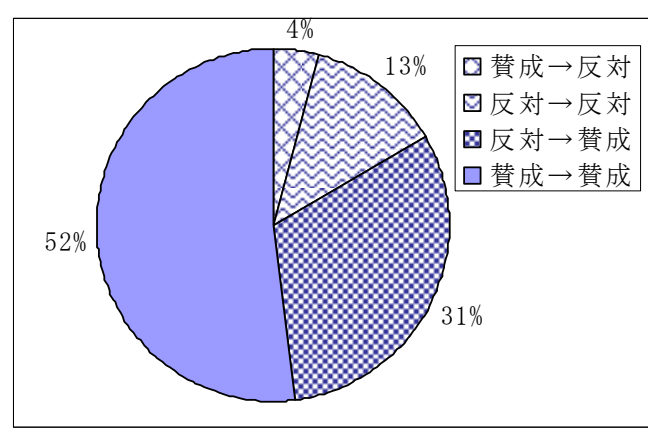

図－5 有料制（超過量方式）に対する賛否

[導入前 $\rightarrow$ 現時点

女性(81\%)および主婦の回答者が多く, 回答者の多く は有料化導入前から A 市および B 町に居住している. シール配布枚数や袋容量は家族構成により異なるが，本 調査では 3〜4 人世帯が多く( $63 \%), 1 \sim 2$ 人世帯( $25 \%), 5$ 人以上の世帯(12\%)は，3〜4人世帯より少ない.

\section{（2）超過量方式に対する評価}

まず，超過量方式による有料制に対する意識が，実際 に有料制が実施される前と実施後の現在で，どう変化し

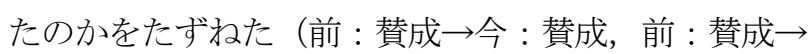
今 : 反対, 前: 反対 $\rightarrow$ 今 : 賛成, 前 : 反対 $\rightarrow 今:$ 反対 のいずれかを選択）。その結果を図ー5に示す，制度導 入以前から有料制（超過量方式）に賛成している割合が $52 \%$ と過半数を占めており，多くの市民が，税金で賄わ れているごみ処理を有料化すべきと考えていたことがわ かる．例えば，両市町と地理的に近い堺市が平成 16 年 度に実施した循環型社会形成に関する市政モニターアン ケートで “ごみの有料化” についてどう思うかを聞いて いるが，その結果では，「賛成である」6.4\%，「どちら かといえば賛成である」16.4\%であり，両者を併せても 
22.8\%の住民しか賛成していない.

また，制度導入前は反対であったが，導入後 7 年経過 した時点では賛成であると評価した世帯は $31 \%$ であ, これらを合わせると，現時点で有料制（超過量方式）に 賛成する割合は 83\%となる，筆者らが 1996 年に市民の 意識調査を行った従量制方式による有料制を導入した $\mathrm{S}$ 市では，導入前の賛成が $20 \%$ ，導入後 4 年経過時で $36 \%$ であったことと比較して高い比率である.このように多 くの賛同を得られた要因の一つが，所定量までは無料で 処理できる超過量方式を選択したことであると考える.

一方，導入前から現時点まで継続して反対の立場であ る世帯は $13 \%$ であり，例え一定量までは処理が無料であ っても反対する人は存在する，なお，導入前に賛成で現 時点では反対という人は少ない.

地方自治体において家庭ごみ有料化が導入される主な 目的は「ごみ減量の推進」，「ごみに対する住民意識の 向上」，「住民負担の公平化」である。では，住民は有 料化の意義をどのように考えているのであろうか. これ について尋ねた結果を図ー6に示す。

住民もごみ減量の推進を通じて「環境保護に貢献でき ること」，「環境意識が高まる（=ごみに対する意識が 高まる）こと」，「負担が公平化されること」をあげて いる.このように，自治体から見た場合のごみ有料化の 目的を，そのまま住民が有料化に賛成する理由としてあ げており，今回，対象とした A市，B町では，住民が有 料制の意義を充分に理解している. これが，ごみ処理有 料制に賛成している人が $83 \%$ れている.

しかし，「減量努力する人としない人の負担が公平」 となることを一番の賛成理由としてあげている人は，上 記有料化導入の $3 つ の$ 目的のなかで最も少ない。これは， 後で述べるが，両市町ともに，多くの市民がごみ排出量 を無料配布シール枚数内に抑えており，現方式では，減 量努力することにより負担が小さくなることがあまり現 象として生起していないことによる.これは，「有料化 導入以前と比べて金銭的負担に変化がない」ことを一番 の賛成理由としてあげている人が存在していることから も判断できる.

次に，現時点でも有料化に反対している人々に，その 理由を尋ねた結果を図ー7に示す。「不法投棄が増える から」といら回答が56\%あり，一部の人々による不法投 棄が招く環境悪化を懸念して有料化に反対している人が 多い. このような意見は，家電リサイクル法導入におい ても頻繁に見聞されたことである，実際，家電リサイク ル法導入直後には家電製品の不法投棄は導入前よりも多 く発生したものの，現在では排出者責任という意識の浸 透や監視・管理体制の整備などによって，顕著な不法投 棄は見られなくなっており，不法投棄に対する確実な対

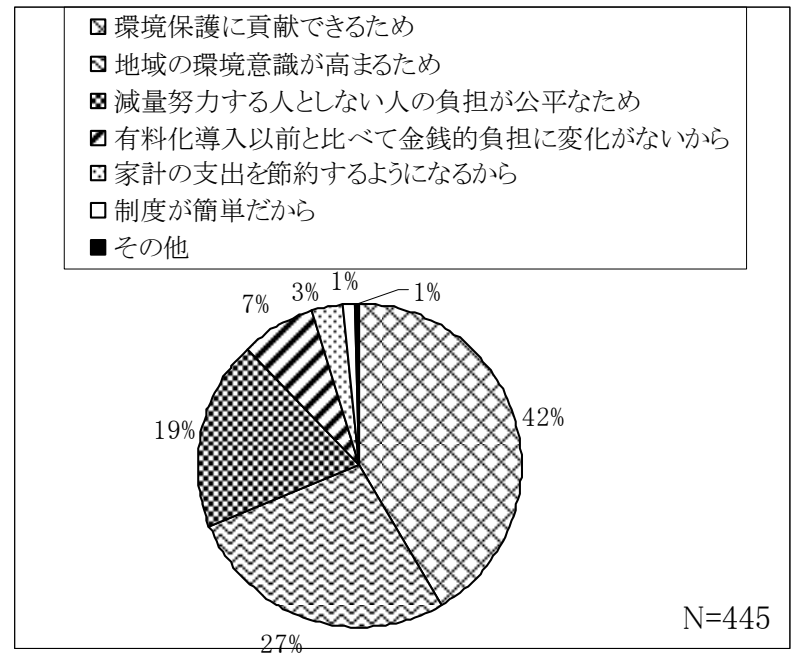

図一6 有料化に賛成できる理由（一つ選択）

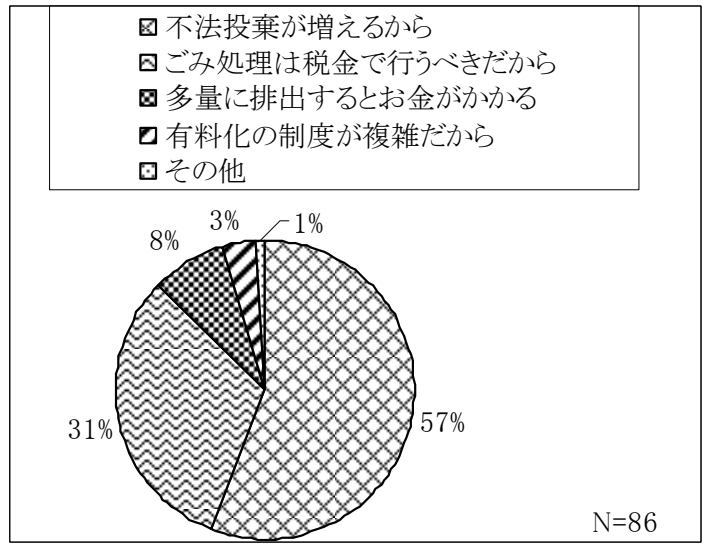

図ー7 有料化に賛成できない理由（一つ選択）

応と，正しい情報を提供すれば，これを理由として反対 している人を減らすことは可能である.

また，「ごみ処理費は税金で支払うべき」であること を一番の反対理由としてあげる人が $30 \%$ に達している. これは，税金を徵収する一方でごみ処理を有料化すると いうことで，市民側としては二重支払いをしているとい う意識が生まれていることを表している，税をどのよう に使っているのかを納税者に知らせるという情報公開を 確実に進めること，およびごみ処理での経費と有料化に よる行政側の収入の関係を明瞭に市民に示していく必要 がある。

なお，「有料化の制度が複雑だから」賛成できないと いう人は少なく，制度の内容から有料化に反対すること はないようである.

\section{（3）超過量方式での無料配布シ一ル数の妥当性}

有料化制度導入直後から現在までの無料配布シールの 使用状況を図ー8に示す．毎年無料シールが余った世帯 が $61 \%$ \%，有料化制度導入当時から無料シールが余り， 現在まで毎年シールが余っている世帯が半数以上を占め ている. 
一方，有料化制度導入当時から無料配布シールをすべ て使ってしまい有料シールを購入し続けている世帯はわ ずか3\%と非常に少ない。これは，A市・B町において設 定した無料配布シール枚数が，大半の市民にとっては過 剰であり，ごみ減量のインセンティブが働かない状況に なっていることを示している.

有料化直後から現在まで毎年，無料シールが余ってい る世帯（61\%，N=337）について, 残余無料シール枚数 の増減をみてみた。これをを図ー9に示寸. 残余無料シ 一ル枚数が「毎年ほぼ同じ」世帯が $42 \%$ と最も多く, 残 余枚数が増加した世帯（「はじめは増加していき，その 後減少」「はじめは増加していき，ある量で落ち着い た」「徐々に増加」と回答した世帯) $25 \%$ と合わせると， 毎年, 無料シールが余っている世帯の 67\%（=全世帯の 約 40\%) では, 制度導入後, 年月が経過してもごみ量は 増えていない. また, 残余枚数が減少している世帯

（「はじめは減少していき，その後増加」「はじめは減 少していき，ある量で落ち着いた」「徐々に減少」と回 答した世帯），言い換えると排出ごみ量が増加している 世帯でも，その多くは減少傾向がある程度で収まるか， その後増加傾向に転じており, 導入後から調査時まで継 続して残余枚数が減少している（排出ごみ量が増加して いる）世帯（「徐々に減少」と回答）は少ない.

これらは，先に示したように，A市・B町において制 度導入から年月が経過することで排出するごみ量が導入 前より増加する，いわゆるリバウンド現象が顕著には表 れていないことを，シール枚数の面から表している.

残余した無料配布シール枚数の増減は, 制度導入後の リバウンドの状況を表すことから，これについて以降で 検討していく.なお, 制度導入後のごみ減量行動への取 り組みについて，図一9に示した残余した無料配布シー ル枚数の増減によって, 表一3のように回答者を区分す ることにした.

\section{5. 超過量方式導入により生起されたごみ減量意 識と行動}

（1）有料化制度導入直後から現在までの減量意識の変化 制度導入直後から現在までのごみ減量意識の変化を図 -10に示す．ごみ減量意識が「少し高まった」世帯が $35 \%$ と最も多く, 次に「高まった」世帯と続いており, 意識が高まった世帯だけで65\%を占めている. 減量意識 が「変わらないせ世帯は23\%であり, ごみ減量意識が低 下した世帯は13\%と少ない.

他都市同様に，A市においても，有料化制度導入によ り，市民のごみ減量意識が高まっているといえるが，有 料制導入によってごみ減量意識の低下した市民がいるこ

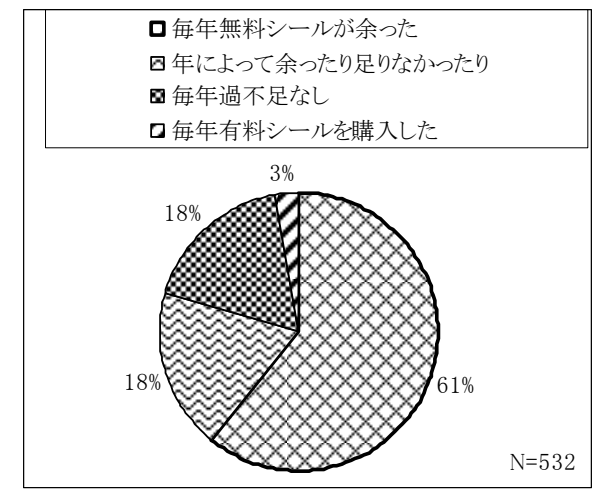

図－8 有料化直後から現在までのシール使用状況

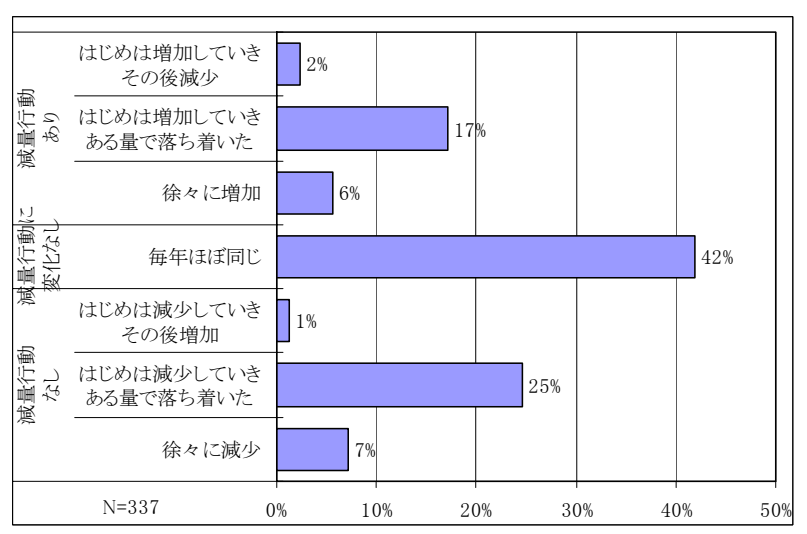

図-9 残余無料シール枚数の変化

\begin{tabular}{|c|c|}
\hline & 表ー3 ごみ減量行動 \\
\hline 区 分 & 残余無料配布シール枚数の変化 \\
\hline $\begin{array}{l}\text { 減量行動 } \\
\text { あり }\end{array}$ & $\begin{array}{l}\text { ○はじめは増加していき, その後減少 } \\
\text { ○はじめは増加していき, ある量で落ち着いた } \\
\text { ○徐々に増加 }\end{array}$ \\
\hline $\begin{array}{l}\text { 減量行動に } \\
\text { 変化なし }\end{array}$ & ○毎年ほぼ同じ \\
\hline $\begin{array}{l}\text { 減量行動 } \\
\text { なし }\end{array}$ & $\begin{array}{l}\text { ○はじめは減少していき, その後増加 } \\
\text { ○はじめは減少していき, ある量で落ち着いた } \\
\text { ○徐々に減少 }\end{array}$ \\
\hline
\end{tabular}

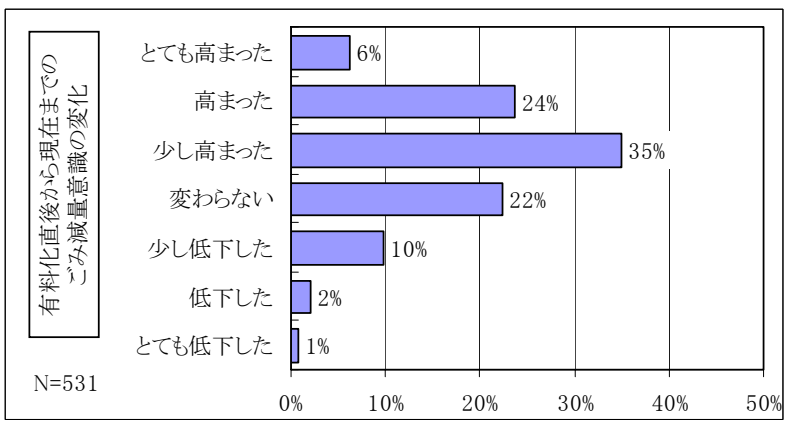

図-10 有料化制度導入によるごみ減量意識の変化

とは無視することができない，A市・B町における制度 が，ある部分で問題を内包していることが窅える結果で ある。

一般に，単身世帯や核家族世帯（とくに共働き世帯） の方が，また，若年世帯の方が，ごみ減量行動を取らな 
いと言われている，そこで回答者の世帯属性（世帯人数, 回答者の年代) とごみ減量行動の関係を解析した. 世帯 属性は，回答者の年代と世帯人数の組み合わせによって, 「小家族世帯」,「核家族世帯」,「大家族世帯」, 「高齢者単独世帯」の4つのカテゴリーに分類した. 世帯属性カテゴリーの分類の方法とサンプル数を表一 4に示寸 (残余無料シール枚数が毎年ほぼ同じと回答し ている人，世帯人数および年代を回答していない人は対 象外である）。

これに従って分類した世帯属性カテゴリーと減量行動 の有無との関係を図ー11に示す．いずれの世帯属性カテ ゴリーにおいても, 減量行動に変化のない世帯の割合が 最も大きく, 次には減量行動なしの世帯割合が大きい.

A市・B町においては, ごみ減量行動の選択において世 帯属性はさほど影響しておらず，高齢者単独世帯で咸量 行動なし世帯の割合と, 小家族世帯で減量行動に変化な し世帯の割合が，他の世帯属性に比較してやや大きい状 況が見られるだけである.

\section{（2）ごみ減量意識と減量行動}

有料化制度導入後によるごみ減量に対する意識（図 －10）と減量行動の区分との関係を分析した結果を図一 12 に示す.

ごみ減量意識の高まった世帯の方が減量行動をしてい る世帯の割合が高、傾向がみられる. しかし，ごみ減量 意識が高まった世帯でも, 減量行動をしていない世帯が $30 \%$ 以上存在する. また，ごみ減量意識に変化がなかっ た世帯においては, 減量行動に変化がない世帯の割合が 約65\%と多くなっており, 低下した世帯では50\%以上が ごみ減量行動をしていない. この様に，ごみ減量の意識 と行動はリンクしてはいるものの, 意識が高まったとし ても，必ずしも行動には結びついているわけではない.

そこで, 次に有料化制度導入後にごみ減量意識が高ま った世帯，低下した世帯を対象に，意識と行動の関連を 分析した.

まず，ごみ減量意識が高まった世帯に対して，その 要因についてたずねた結果（複数回答あり）と, 減量行 動の有無との関係を分析した. これを図一13に示す. 減 量行動を行っている人と行っていない人，どちらもごみ 減量意識が高まった要因として最も多くの人があげたの が，有料化制度導入により「環境問題に関心を持つよう になった」ことである.この意識変化は有料化制度導入 による大きな効果である.

しかし，環境問題に関心を持つことと，ごみ減量行 動を行うこととは必ずしもリンクしておらず，実際には ごみ減量行動を行っていない人々でも，その $47 \%$ は環境 問題に関心を持つようになってごみ減量意識が高まった としている，減量意識が高まっても，ご多減量行動は実
表一４世帯属性カテゴリーの分類方法とサンプル数

\begin{tabular}{|c|c|c|c|c|}
\hline & \multicolumn{3}{|c|}{ 世帯人数 } \\
\hline & & 1 2人 & 3〜4人 & 5 人以上 \\
\hline \multirow{3}{*}{$\begin{array}{l}\text { 年 } \\
\text { 代 }\end{array}$} & 30 代以下 & 小家族世帯 & 核家族世带 & \multirow{3}{*}{$\begin{array}{c}\text { 大家族 } \\
\text { 世带 } \\
(96)\end{array}$} \\
\hline & 40～50代 & (36) & (129) & \\
\hline & 60 代以上 & $\begin{array}{c}\text { 高齢者単独世 } \\
\text { 帯(52) }\end{array}$ & & \\
\hline
\end{tabular}

( )内はサンプル数

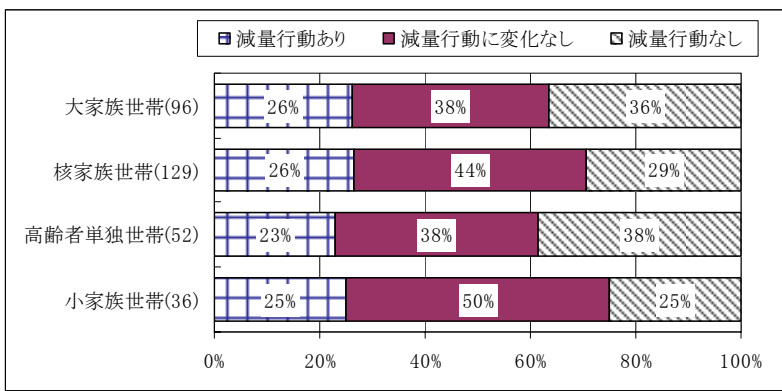

図ー11 世帯属性カテゴリーと減量行動の有無

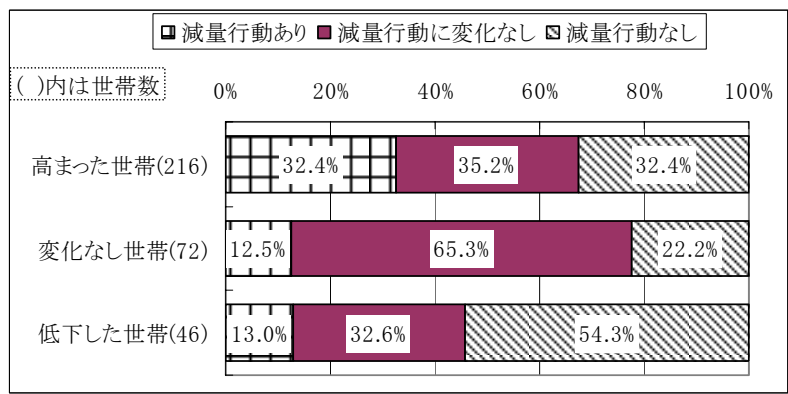

図-12 有料化制度導入後のごみ減量意識と 減量行動の有無の関連

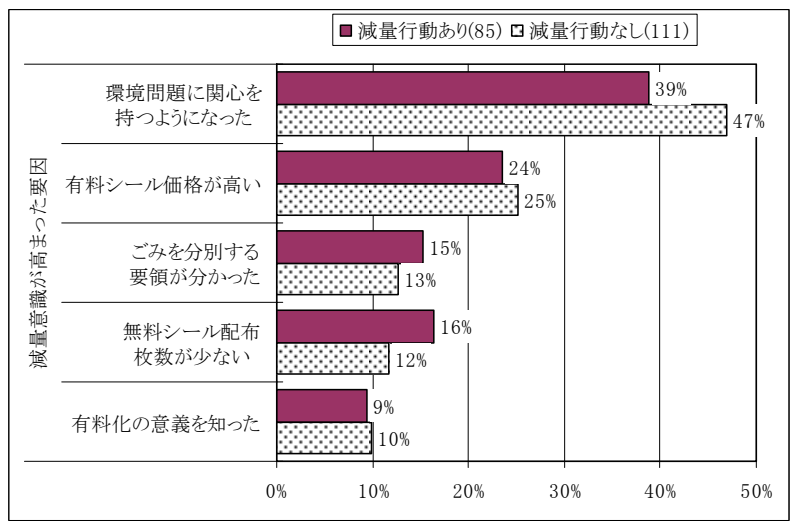

図ー13 減量意識が高まった要因と減量行動の有無

行されていない.

また，「有料シール価格が高い」ことを要因と挙げ た人々が2番目に多かったことから，一定量を超過した 後にごみを排出するために必要となるシールの価格が高 いことも，ごみ減量行動を選択させることにつながって いる，一方，減量行動を実行している人々の方が，ごみ 減量意識が高まった要因としてあげた比率が明確に高い 要因はないが，「無料シール配布枚数が少ない」ことで は差が見られる。 
筆者らの予想に反して, 有料化制度をなぜ導入する のかを理解することは, 本制度によるごみ減量行動励起 にはほとんど寄与していない（「有料化の意義を知っ た」ことを要因としてあげている人が少ない）。

一方，有料化制度を導入したにも関わらず，ごみ減量 意識が反対に低下してしまった人々も全体の $13 \%$ 存在し ているが (図一10参照)，これは何故なのかを考察した。 図ー14に減量意識が低下した理由をたずねた結果を示す。 「減量を意識しなくてもシール配布枚数の範囲内に収め ることができる」ことが最も理由として多い.

やはり, 当初に無料て配布されるシールの枚数が過剩 なことがごみ減量行動を促さず，ごみを減量しようとい う意識も形成させない大きな要因となっているようであ る.

\section{（3）有料シ一ル購入 - 無料シ一ル残余状況とごみ減量意 識}

有料シールの購入状況ならびに残余した無料配布シー ル枚数が，人々のごみ減量意識形成にどのように影響し ているのかを考察した.

年間の無料シール配布枚数は世帯人数によって異な るので, 調査前年度のごみ処理シール使用状況を世帯人 数別に整理した. これを図ー15 に示す. どの世帯人数 でも無料シールが余った世帯と過不足なしの世帯でほと んど占めており, 有料シールを購入した世帯は少数であ る. 本制度導入により, ある程度のごみ減量行動を誘導 できていると推測できるものの, 有料化制度導入後, 7 年を経過した現在では, 導入時に設定した条件では無料 配布シール枚数が過剩となっている. 余剩したシール枚 数は 6 10枚であると回答した世帯が最も多く, 次いで 5 枚以下，11〜20 枚の順で，21 枚以上余剩する世帯は少 ない（図一16）。ごみ排出量が微増している現状を鑑み ると，導入した方式の内容を見直すべき時期にきている. 前年度の無料シール残余状況によって，翌年にどの ようなごみ減量意識を持つようになっていたのかを分析 した. 無料シールが余った世帯での状況を図ー17(a)に， 有料シールを購入した世帯での状況を図ー17(b)に示す. 無料シールが残余しても不足しても，「無料シールが 不足しないように減量努力」しようと意識している世帯 が多い. とくに, 有料シールを購入する状況になった世 帯の方が, より減量意識は高い. したがって, 超過量方 式では，“無料で排出できるごみ量”が，各世帯におけ るごみ排出の目標として明確に意識されることが本分析 より立証できている.

さらに，無料配布シールが余るように「さらに無料 シールが余るように減量努力」しようという意識が形成 されている世帯も多い.

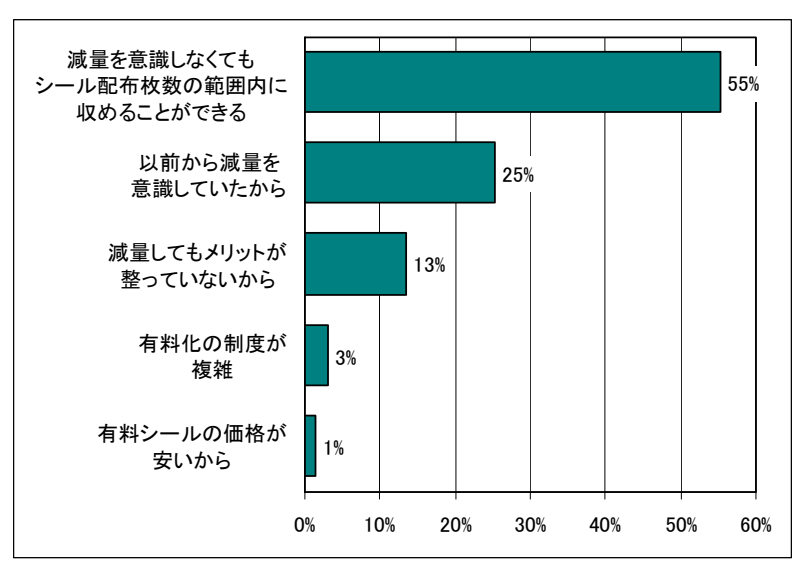

図ー14 減量意識が低下した要因

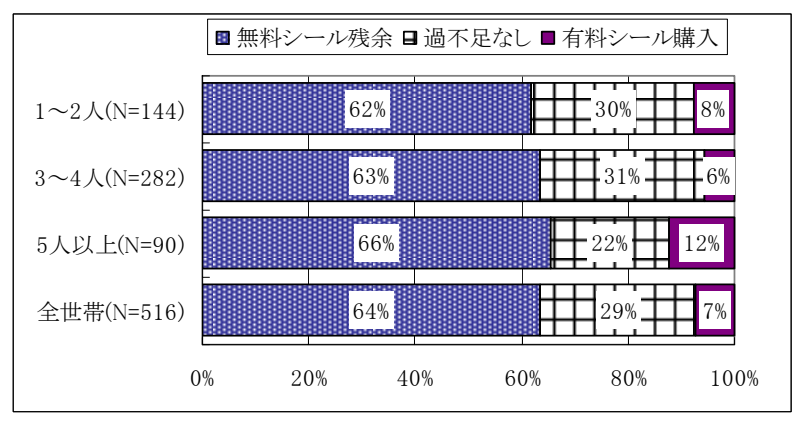

図ー15ごみ処理シール使用状況

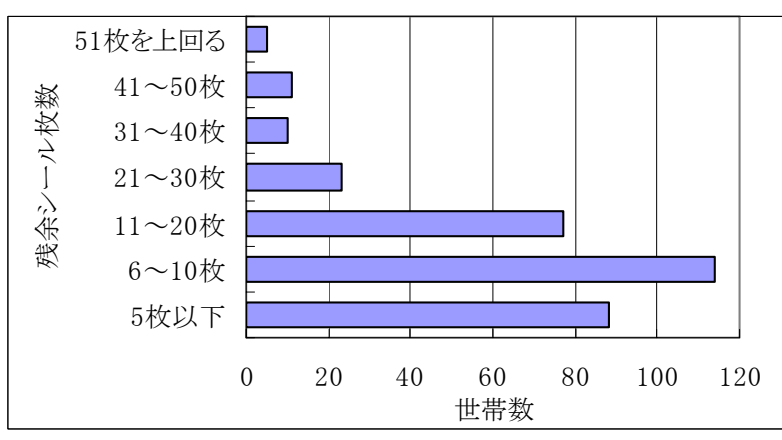

図一16 無料配布シール残余状況

結局，今回調查した自治体のように無料配布シール枚 数が多めとなっている超過量方式では, 制度導入により 有料化の意義の理解や有料シールによるコスト負担増の イメージングによってごみ減量意識の形成は促せるもの の，それだけではごみ減量行動を実行させるにまでは至 らない. かえって, ごみ減量意識が低下して, 実際にご み減量行動も起こさない結果を招く場合もある. 多くの 住民にごみ減量行動を実行してもらうには，無料配布シ 一ル枚数の設定と有料シールの值段の設定に十分な留意 が必要である。 


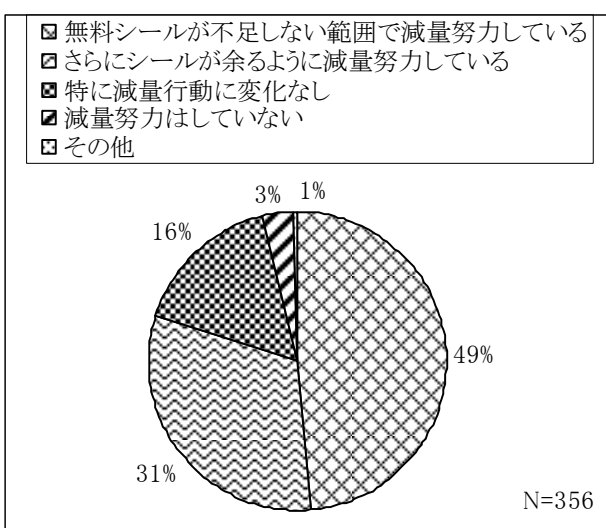

図ー17(a) ごみ減量意識（無料シール残余世帯

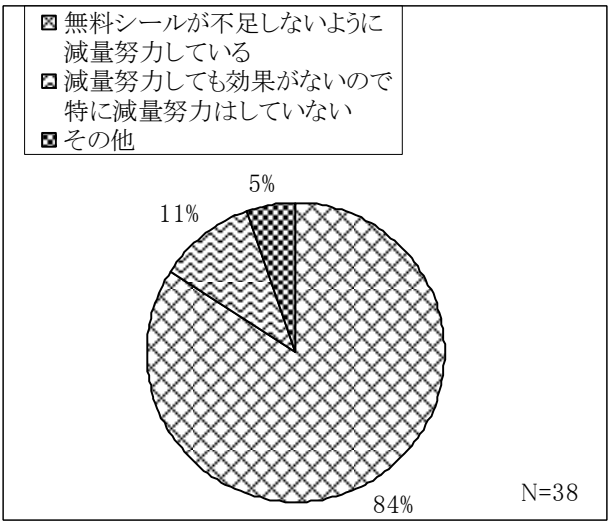

図ー17(b) ごみ減量意識（有料シール購入世帯）

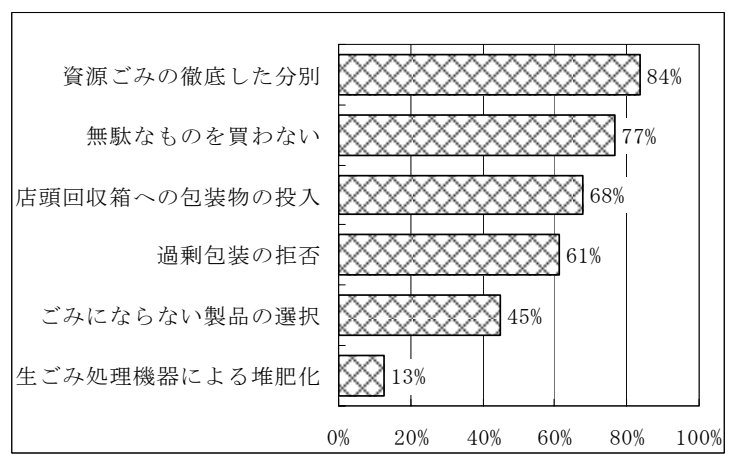

図-18 実践しているごみ減量化行動（複数回答）

（4）超過量方式導入により生起されたごみ減量意識と行 動

いわゆる，“環境に配慮しようとする意識の形成”に は, ( i 環境リスク認知（環境污染による被害の深刻さ やその発生可能性についてのリスク認知），（ii 責任帰 属認知（環境污染の原因がどこにあるかという責任帰属 の認知），（iii 対処有效性認知（なんらかの対処によっ て環境問題を解決できるとする対処有効性の認知）が関 与するとされている.

さらに，形成された環境配慮意識を環境配慮行動に 結びつけるには，（）実行可能性評価（考えている環境 配慮行動を実際に自分が実行可能であるかどうかの評 価），（ii 便益費用評価（環境配慮行動に切り替えると，
今までよりも便利さや快適さがどれほど損なわれるかの 評価，ある程度の手間やコストを受忍できるか㧵かの評 価），( iii 社会規範評価（意図する行動が近隣や社会の 規範に合致しているかどうかの評価）が関わるとされて いる9?.

超過量方式という有料化制度は，無料配布シール枚数 内でのごみ排出という明確な目標を提示することで，環 境配慮意識形成における対処有效性を，市民に認識させ ていると判断できる.さらに，実際に行動を実践してみ て，その結果の良否を，有料シールの購入が必要な状況 になったか否かということで，毎年，認識させるため， 便益費用評価（ご2減量の手間，有料シールを購入しな くて済む等）や社会規範評価（近所の人は有料シールを 購入していない等）を行わす という効用がある，そし て, 自らの行動を振り返り, 対処有效性をさらに認知 (ごみ減量に努めたことで無料シールが余った．さらに これを増やすことが次の目標になる）さ）させいること もわかる.

したがって，超過量方式は，ごみ減量意識を形成する が，それだけではごみ減量行動を促すまでに至らず，こ れに便益費用評価が加わってごみ減量行動に結びつけて いく効用を持つといえる.

実際，どのような環境配慮行動（ごみ減量行動）を実 践しているかを尋ねた結果，図一18 に示すように,

「資源ごみの分別」，「無駄買いをしない」，「店頭回 収箱一投入」，「過剩包装の拒否」は 60\%以上の人が，

「ごみにならない製品の選択」も $45 \%$ の人が実行してい る. 単なるリサイクルへの補助行動（資源ごみの分別排 出など）に留まらず，ごみになるものを極力持ち帰らな い行動（Refuse，Reduce）を実践している.

環境省による平成 15 年度の『環境にやさしいライフ スタイル実態調査』での「買い物袋を持参したり過剩な 包装を断ったりしている」という行動の実行率が 32.5\%, 電通の『2002「生活者の環境意識と行動」調査報告書』 での「過剩包装の商品は買わない」という行動を実行し ている人が $18.6 \%$ と比較して，A 市・B 町住民の「過剩 包装の拒否」実行割合は高くなっている.さらに，「ご みにならない製品の選択」においても，環境省調査 $37.6 \%$ ，電通調查 $18.1 \%$ （「使い捨て商品は買わない」と いう質問）であり，A市・B町住民の方が実行する人の 割合が高い，調查対象は異なるものの，A 市・B 町住民 は Refuse, Reduce につながる行動を他地域よりも多くの 割合で人々が実行しているといえる.

このように，一般にごみ減量効果が継続しない方式で あるといわれる超過量方式であっても，人々はごみ処理 の有料化という制度変革を転機として，自らの行動を見 直し，様々な環境に関わる情報を吸収して，その行動を 環境配慮のものに変えている. 
しかし，このような効用をより高め，さらに持続させ ていくためには, ISO14001における PDCAサイクルのよ うに，人々の環境配慮行動の実践状況に合わせて，目標 をより高いものへシフトしていく必要がある. すなわち, 無料で排出できるごみ量を減らすことである. 天野ら ${ }^{10)}$ も指摘しているように，無料配布枚数を少なくするほど ごみ減量効果があり，世帯人数よりも「無料で配られる 枚数が多いか少ないか、という要因の方が家庭ごみ排出 量に強い影響を与えている.

\section{6. 超過量方式導入によるごみ減量行動促進策}

\section{（1）ごみ減量意識が高まった世帯におけるごみ減量行動 影響要因分析}

ここでは，ごみ減量行動と意識の関連性の分析から， 超過量方式を導入することによってごみ減量行動を促進 させる方法を考察した. 分析手法には，カテゴリー的な 目的変数である外的基準を定性的な説明変量であるアイ テム・カテゴリーにより, 外的基準の予測や要因の相互 の関連性を分析する数量化理論 II類を用いた.

有料化直後から現在までの無料シールの残余状況の設 問への回答において，無料シール枚数が増加している世 帯を「減量行動あり世帯」と定義し，外的基準変数を

「減量行動の有無」とした.

説明変数には，ごみ減量意識として，有料化直後と現 在におけるごみ減量意識に関する設問である「減量意識 が高まった理由」と「減量意識が低下した理由」とした. また, 属性も減量化行動に影響寸ると考え, 属性も説明 変数とした. なお，分析にあたり，説明変数の属性は属 性間の 2 変量の相関が高いものは, 目的変数との相関が 低い方を削除したり，偏相関係数ならびに相関比が高く
なるように選択し，最終的に属性の説明変数として「居 住形態」，「世帯属性カテゴリー」を採用した.

上記の目的変数と説明変数を用いてごみ減量行動と意 識の関連性について分析を行い，ごみ減量行動の有無に 影響を与える要因を考察した.

数量化理論類の解析によって得られたカテゴリース コアとレンジ（範囲），偏相関係数を表一5に示す．な お，表中の報奨金とは，前年度に余剩したシールを自治 体側が買い戻す際に支払うお金のことである．A市では 30L袋用シールには15円，40Lには30円を支払っていたが， 現在はこの制度は廃止している。

解析結果の相関比は， $\mathrm{R}=0.415$ で，分析の精度を表す 判別的中率は，67.5\%であった．また，レンジの信頼性 を調べるためにレンジと偏相関係数を大きい順にみてい くと，その順位は大幅に違いがないことから，本研究に おける解析結果は妥当であると判断した.

レンジと偏相関係数より, 減量意識が高まった世帯に おいて減量行動に取り組むか研かに最も影響を与えてい るのは「居住形態」であることがわかる．一般的に戸別 住宅より空間的に余裕が少ない集合住宅では，減量行動 に取り組みにくい状況にあることが現れている.

意識に係る要因では，影響度が大きい順に「有料シー ル価格が高い」，「ごみを分別する要領がわからない」, 「無料シール配布枚数が少ない」であった. 有料化の意 義や環境問題への関心は，ごみ減量行動の実践にはさほ ど影響していない.

有料シール価格が高いと考えている人，無料配布シー ル枚数が少ないと考えている人，ごみを分別する要領が わからない人が，ご減量行動を実践している，すなわ ち，次のように有料制を捉えて，ごみ減量行動を実践す るようになったと推察できる.

表ー 5 ごみ減量意識が高まった世帯における数量化理論 II 類解析結果

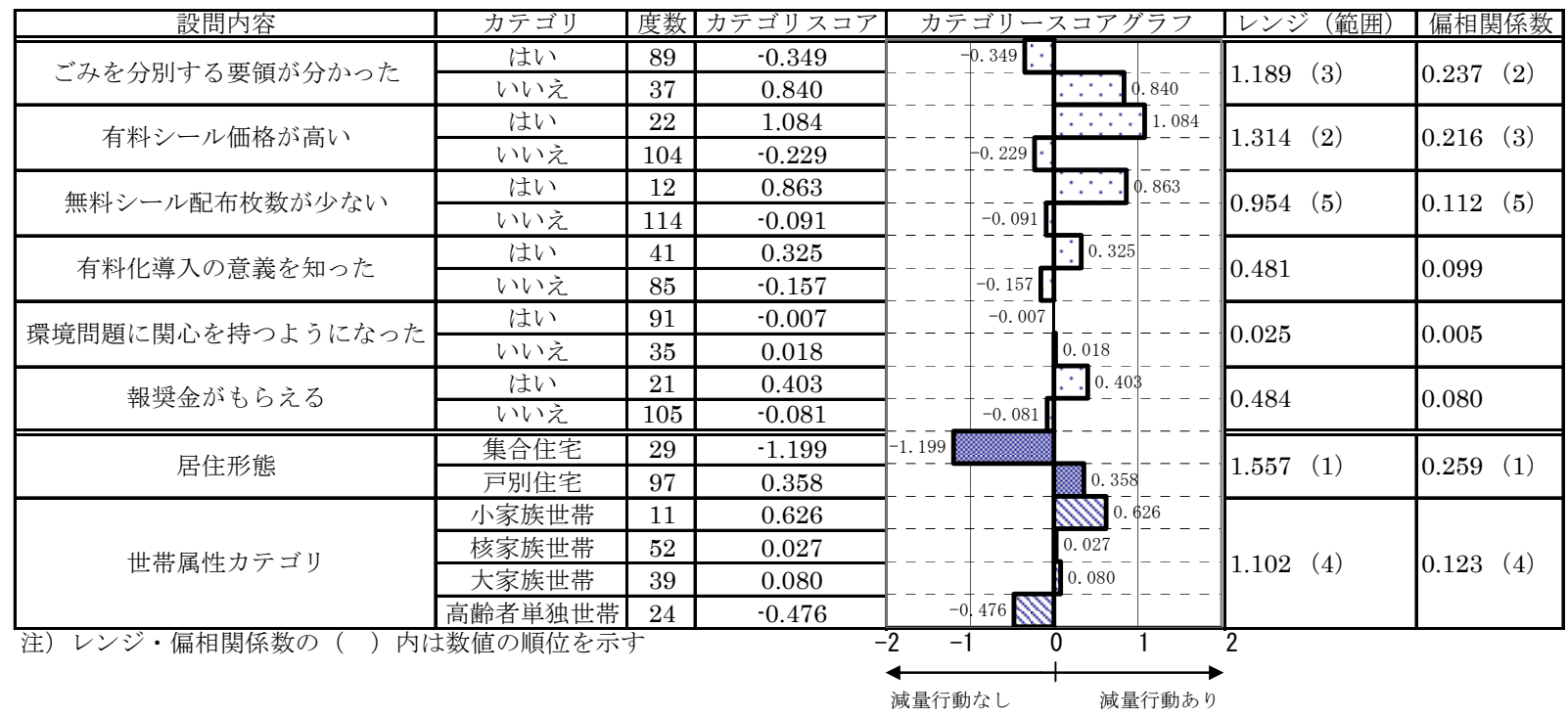


1. これまでのごみ排出状況では新たなコストが生 じる（無料シールの配布枚数が少なく, 価格が 高いと思う有料シールを購入しなければならな くなる）ことから，これまで通りのごみの排出 では良くないことを認識.

2. 有料化対象でごみを少なくするには，分別を要 領よく行って ‘ごみ’として排出していたもの を“資源” として分別・排出するのが容易な手 段である. しかし，“資源’ とするために要領 よく分別する方法がよくわからない. したがっ て，どうにかごみを減量化したいと意識.

したがって，実際にごみ減量行動を実践させるには， 有料シール価格を高めること, 無料配布シール枚数を減 らすといった便益費用評価面での意識の行動への結びつ けを強めることである.

\section{（2）ごみ減量意識が低下した要因}

今回対象とした自治体では，少数派ではあるが，制度 導入後にごみ減量意識が低下した世帯が存在した，その 要因を, これまでの分析結果から考察してみる.

前述したように，毎年，無料シールが余った世帯が 61\%にものぼり, 設定している無料配布シール枚数が多 すぎるのが現状である. やはり，超過量方式において無 料配布シールが多いことは, 有料制導入のひとつの目的 である，人々のごみ減量意識の向上をもたらさない，無 料配布シールが多いことは, 結局, 便益費用的な視点か らは，「減量してもメリットがない制度であることで あり，これではごみを減量しようという意識は形成され にくい. 経済的なメリットを重視する人にとっては, 所 定の量以上に減量努力しても経済的には何も報われない 方式である. この点は, 超過量方式のウィークポイント のひとつである. この点に関しては, 有料シールを購入 する世帯の比率があるパーセンテージを下回った段階で 無料配布シール枚数を見直すことが必要である.

\section{（3）超過量方式導入によるごみ減量行動促進策}

以上の分析より, 超過量方式によるごみ処理有料化に よって，市民にごみ減量へのインセンティブを働かせる ためには,

(i) 無料配布するごみ袋の枚数と容量

(ii) 一定量超過時の指定ごみ袋や指定シールの価格 の適正設定

といった便益費用評価面での対応が，重要な鍵となるこ とが判明した。

実際，対象としたA市とB町では，かなりの割合の世 帯が無料配布シールを余らせている. 有料化導入後, 既 に7年を経過しているため, ごみ排出量が微増している 現状も考慮して，無料配布枚数を見直す時期にきている.
その上で，環境管理におけるPDCAサイクル（計画 Plan一実行Do一評価Check一改善Act-Cycle) 同様に, 導 入した制度による結果を評価し，そして，的確な改善策 を創り，再びこれを計画・実行していくという，好循環 を創り出すことが必要である.

さらに，このような経済的インセンティブをより有用 なものとするために，人々の行動選択肢の中に，環境配 慮の行動を増やすように, 環境コミュニケーションを進 めていくことも必要である.

\section{7. 結論}

一般家庭ごみ処理の有料化は，今後のごみ処理におけ る基本的な流れである。しかし，これだけ環境を重視し た生活やライフスタイル（商品選択，ごみ分別，資源化 など）が重要であることが認識されている状況にあって も，やはりこれまで長年にわたって無料であったものが 有料化されることに対する市民の反発は, 当然, 大きい ものと予想される.

そのような状況にあって，現時点では少数派であるも のの, 市民が受け入れや寸い超過量方式という有料化制 度は，今後，もう一度見直されるものであると筆者らは 考えている.

本論文で明らかにした超過量方式の有用性を以下に列 挙する.

1) 本方式を実際に導入している市町では，市民の 83\%という高い割合で有料化という制度に賛成し ており，超過量方式は従量制方式に比較して市 民の賛同を得られや寸い方式である.

2) 超過量方式は単純従量方式にない特徵として, 具体的な目標を市民に提示寸ることができ，こ れにより，より多くの人々にごみ減量意識を形 成させていく．環境に配慮したいと思っている 市民にとって，具体的な目標が設定されること は，環境配慮行動を実践する場合の励みとなり， 実効性のある行動を選択させる.

3）ごみ処理有料化導入においてよく議論されるの が，導入後の排出量のリバウンドであるが，本 方式は設定した一定量を超えないようにする行 動を誘引できるため, リバウンドが生じにくい.

4) さらに，少数派ではあるが一部の人々は無料配 布シール枚数以下にごみ排出量を抑えるだけで なく, 無料で配布されたシールの残余量を新た な目標として, さらなる環境配慮行動の実践に 取り組むようになる。“無料配布シールが余 る”という明確な結果が，さらなる環境配慮行 動を導いていく. 
一方，本方式を導入する場合の課題としては，次のも のがあった.

1) 無料配布シールが多いと，人々のごみ減量意識 の向上をもたらさず, ごみ減量行動を誘引でき ない.

2)経済的なメリットを重視する人にとっては，所 定の量以上に減量努力しても経済的には何も報 われない方式であるため, ごみ減量行動に取り 組多にくい.

しかし，これらデメリットは，適切な無料配布シール 枚数の設定をすれば解消できるものである.

したがって, 超過量方式も, 今後の一般廃棄物処理に 導入する有料化の制度として，十分に検討に值するもの であると判断する.

本論文が，有料化制度導入において，多少なりとも寄 与できるものであると信じる.

謝辞 : 調査にご協力いただいた自治体担当者など関係各 位に厚く御礼申し上げます，また，アンケートの作成・ 分析では関西大学工学部都市環境工学科助手尾崎平氏に, アンケート調査・データ入力等では同学科環境システム 研究室一同に多大なる協力を得たことを感謝します。

\section{参考文献}

1) 京都市廃棄物減量等推進審議会 : 今後のごみ減量施策の あり方一指定袋導入の具体的あり方について（答申）(案) , 2005.

2) 福岡市：福岡市家庭ごみ有料化 Web ページ http:/kankyo.city.fukuoka.jp/148_index_msg.html, 2005.

3) 札幌市 : 第5回さっぽろごみゼロ会議資料, 2004.

4) 札幌市廃衰物减量等推准審議会: 第2 回部会資料, 2005.

5) 山谷修作 : 最新家庭ごみ有料化事情一第 2 回アンケート 調查より一第 1 回家庭ごみ有料化の現状, 月刊廃裹物, 31(7), pp. 52-63, 2005.

6) 山谷修作 : ごみ有料化施策と市民の反応，月刊廃衰物， 26(12), pp.48-53, 2000.

7) 山川肇,植田和弘, 寺島泰 : 有料化によるごみ減量効果の持 続性，土木学会論文集，No.713，pp.45-58，2002.

8）山川肇，植田和弘，寺島泰 : 有料化実施時におけるごみ 減量の影響要因, 廃衰物学会誌, 13(5), pp.262-270, 2002.

9) 広瀬幸雄:環境と消費の社会心理学, 名古屋大学出版会, 1995.

10）天野耕二，松浦篤史 : 家庭ごみ排出特性に関わる指定袋 配布制度の評価, 廃棄物学会論文誌, 13(2), pp.63-70, 2002.

(2006. 2.9 受付)

\title{
FACTOR ANALYSYS OF WASTE REDUCTION THROUGH VARIABLE RATE PROGRAM WITH TWO-TIER PRICING
}

\author{
Yasuhiko WADA, Hiroyuki MIURA and Kazuko NAKANO
}

\begin{abstract}
Variable rate program with two-tier pricing is in the minority in Japan. But, this method has an advantage that to show a goal to reduce waste. This goal setting make people have garbage awareness and sense of recycling. The specific goal setting serves as a source of encouragement for people who want to give consideration to global and local environment, and that make people choice several environmental conscious actions. The other way, if the amout of rubbish that are collected free of charge is much then people do not have garbage awareness and sense of recycling. And, because there is not an economic merit for such people, these people do not waste reduction action. Therefore, decisions of the number stickers for waste bag that are given out free of charge and the collection charge of a case beyond quantity of setting garbage collection in variable rate program with two-tier pricing.
\end{abstract}

